\title{
Introduction to Bolivia
}

T $\mathrm{n}$ the geographical heart of South America, landlocked and often isolated Bolivia has for centuries intrigued fortune-seekers, adventurers, and travelers alike. One of the most culturally, physically, and ecologically diverse places on the planet, Bolivia soars over two Andean mountain ranges and the high, cold plateau between them known as the altiplano, before dropping eastward through high, dry valleys and then plunging into the dense humidity of the Amazon basin in the north and the arid, dusty Chaco plain to the south.

Although two-thirds of its territory is lowland, most outsiders only know its western mountainous region, home to the majority of its 9 million people. Roughly 65 percent of Bolivians consider themselves indigenous, the highest proportion in the Americas. Most are Aymara or Quechua speakers in the western altiplano and high valleys. The peoples commonly known as "the Quechua" are in fact a conglomeration of different ethnicities forced by the fifteenth-century Inka conquerors to adopt their language, religion, and culture. The Aymara in the northern highlands, who only developed a sense of separate ethnic identity in the eighteenth century, have successfully clung to their own language despite repeated efforts by the Inka, Spanish, and Bolivian elites to exterminate it (Rivera I987). The Guaraní, about I50,000 in all, are the third-largest group, living in the southeastern lowlands, where they form the northern extension of the much larger Guaraní population in Paraguay. As many as thirty-five other, smaller groups, among them Chiquitanos, Ayoreos, Chimanes, and Moxeños, totaling another I50,000, live scattered throughout the eastern lowlands.

About 25 percent of the population identify themselves as mestizos: strictly speaking, those of mixed European and indigenous heritage. But given the fluidity of indigenous identity, in practice, mestizos are usually urbanized people of indigenous heritage who largely reject their culture of 


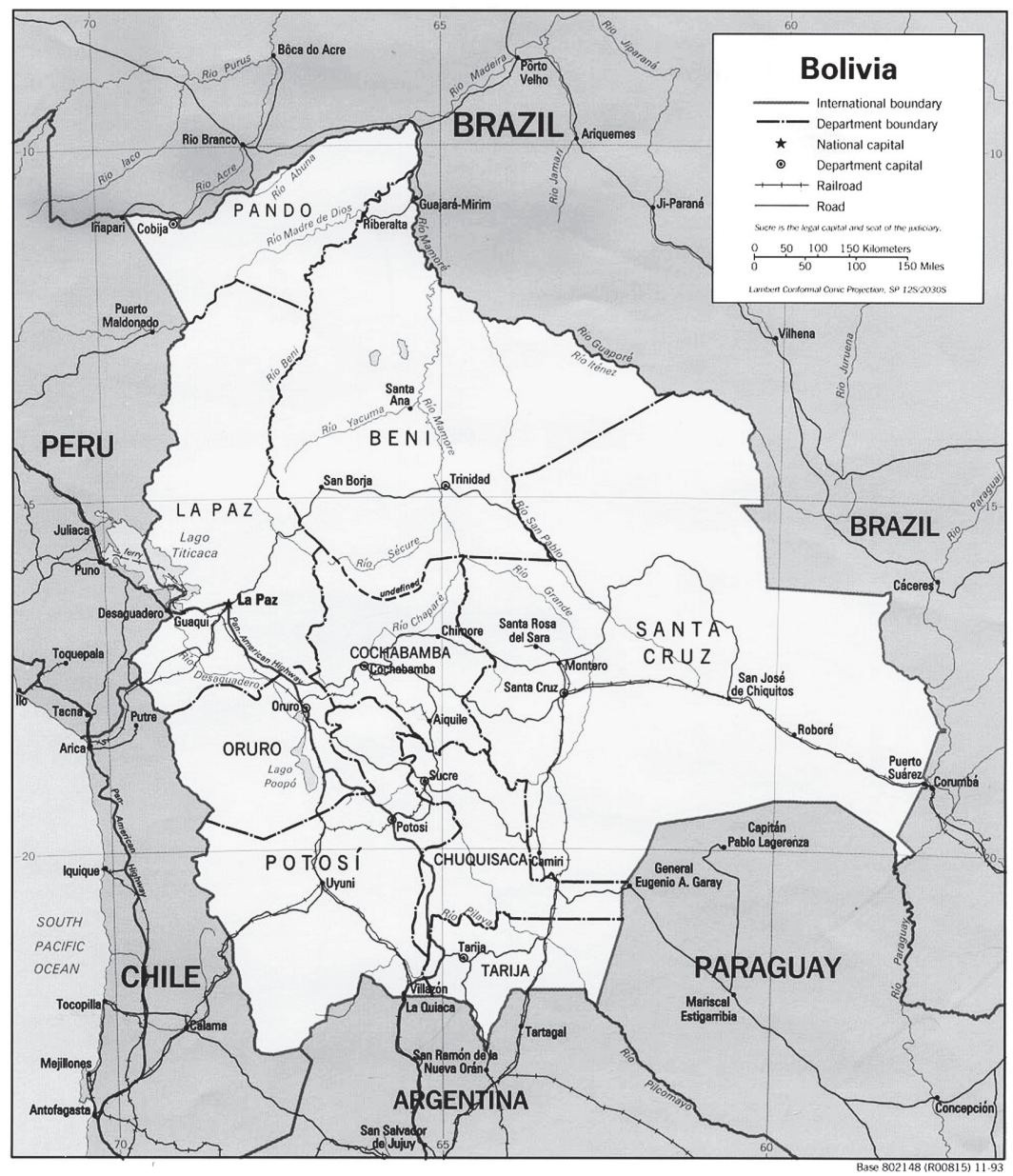

Bolivia. Courtesy of University of Texas Map Library.

origin's customs. Though smallest in number, the most powerful economic and political group, comprising less than Io percent of the population, is an elite claiming pure European heritage, known as criollos.

Since the sixteenth-century Spanish Conquest, Bolivia has almost invariably served the needs of foreigners and the national criollo elite. The dominant economic pattern, no matter what the economic and political model, has been based on the export of Bolivia's vast natural resources. Shaped by resource boom-and-bust cycles centered on silver, tin, quinine, rubber,coca, and, most recently,natural gas (Morales 20Io), Bolivia's economic foundation closely resembles that of other countries that supply primary 
materials to international markets. Even though it gained independence from Spain in 1825 , the legacy left by colonialism and a rapacious extractive economy has persisted, profoundly damaging the physical environment and creating one of the most extreme cases of economic dependency in Latin America (Farthing 2009; Malloy and Gamarra I988). It has also highly skewed Bolivia's income distribution: according to the United Nations Development Programme (HDR 2009), the country was second only to Haiti as the most unequal in the world's most unequal region, with Io percent of the population controlling 40 percent of all income and an even greater share of land and other wealth.

Resistance by the indigenous majority to this domination has been a constant (Thomson 2002). Until the 1952 revolution brought the first promise of citizenship, indigenous people had few rights and little place other than as a source of labor and tax revenues. The revolution successfully overthrew the country's mining oligarchy thanks to a coalition drawn from the tiny middle class, a burgeoning labor movement based in the mines, and the indigenous majority. Latin America's second revolution (after Mexico's) wrought profound changes in a dependent and virtually feudal country, granting the vote to indigenous people and women, nationalizing the mines, breaking up the large estates (haciendas) in the western part of the country, and redistributing land to indigenous people.

The middle-class-dominated government that grew out of the 1952 revolution was generally moderate, following other Latin American countries along the path of import-substitution industrialization. This aimed to protect local industries by forging a strongly centralized state administration that controlled natural resources and shifting 70 percent of the economy into government hands.

In I952, the labor movement formed the Bolivian Workers Central (Central Obrera Boliviana, or COB), which cogoverned with the new administration during the I950s, pushing it to institute its most radical changes, such as nationalization of the mines and partial land reform. In the late I970s the COB, which served for almost forty years as Bolivia's primary force for social and economic justice, brought down the military dictatorships that plagued the country between I964 and I982, and played a crucial role in the country's often halting return to democracy (Dunkerley I984).

While the 1952 revolution certainly improved life for the majority, the criollo minority maintained much of Bolivia's exclusionary society intact and blocked indigenous peoples from fully integrating socially, economically, and politically. This created a deeply fractured country where social unrest and conflict have been the norm. Despite the Agrarian 


\section{INTRODUCTION TO BOLIVIA}

Reform in 1953 , about 12 percent of landowners still control 90 percent of the farmland (Weisbrot and Sandoval 2008). In a country where almost half the population lives in the countryside, over 80 percent of people there are poor, giving Bolivia one of the region's highest rural poverty rates (PicaCiamarra 2009).

In I985, Bolivia experienced one of the earliest and most radical neoliberal restructuring programs, under the aegis of the three major international financial institutions (the World Bank and the International Monetary Fund).The rapid control of hyperinflation by the "New Economic Policy" appeared almost miraculous, turning the country into a global poster child for neoliberalism's successes. But the cost to workers was enormous: over fifty thousand lost their jobs, and the labor union movement was virtually destroyed. By I988, almost 70 percent of the urban workforce worked in the informal economy (Farthing 1995).

International development assistance was a central element of economic stability, growth, and development. Aid per capita was estimated as high as US $\$ 75$ per year, three times the average for the world's least developed countries, and more than twice the average for countries receiving debt relief assistance. Until the election of Evo Morales' government (2006-) and his party Movement towards Socialism (Movimiento al Socialismo, or MAS), aid was particularly crucial to government functioning and estimated to make up between 7 and 9 percent of annual gross domestic product (GDP) (Weisbrot and Sandoval 2006).

Despite efforts to create a modern state and expand private investment, both domestic and international, neoliberalism ultimately failed to solve Bolivia's recurring difficulties: attracting broad-based investment, improving living standards, addressing indigenous demands for basic rights and resources, and balancing demands from the regions for more local control (Kohl and Farthing 2006).

By the end of the I990s, growth had stagnated, and neoliberalism's failure to deliver on its promises led to a resurgence of social protest. In 2000, Bolivia gained a global spotlight as a symbol of resistance to neoliberal globalization. From the 2000 Cochabamba "water war," which successfully overturned the privatization of the city's water supply, to the 2003 and 2005 "gas wars," which ousted two presidents, social movements have demonstrated the ability of poor people in a small, marginal country to successfully challenge powerful companies, governments, and institutions (Hylton and Thomson 2007). In a significant victory in December 2005, participants succeeded in finally electing one of their own as president: the indigenous, left-wing leader of the Chapare coca growers, Evo Morales.

Despite being thwarted by weak administrative capacity in many xxvi 
government ministries, sometimes violent opposition from the right-wing oligarchy, particularly in the eastern lowlands, and Bolivia's historically fractious left, the Morales administration accomplished a great deal during its first term in office. The resounding mandate Morales won in 2005 allowed him to convene a Constituent Assembly, enact a partial recovery of hydrocarbon resource rents, and increase the participation of historically marginalized groups in the state (Kohl 20IO). 
THIS PAGE INTENTIONALLY LEFT BLANK 
From the Mines to the Streets 
THIS PAGE INTENTIONALLY LEFT BLANK 